\title{
Relationships between production and fertility traits in first lactation and life time performances of Holstein cows under subtropical condition
}

\author{
MUSTAFA TEKERLI and SERDAR KOÇAK
}

Department of Animal Science, Faculty of Veterinary Medicine, Afyon Kocatepe University, Turkey

\begin{abstract}
The objective of this study was to determine the relationships between milk yield and calving interval in first lactation and breeding efficiency, herd life and length of productive life of 1293 Holstein cows maintained at Ceylanpinar State Farm in Southeast Anatolia from 1990 to 2002.

The least-squares means of first lactation milk yield, lactation length and calving interval were $5620.1 \pm 76.6 \mathrm{~kg}, 315.5 \pm 2.0$ and $386.9 \pm 2.6$ days. The values for breeding efficiency, herd life and length of productive life were $94.9 \%, 2095.9 \pm 34.7$ and $1257.2 \pm 34.4$ days. The year of first lactation had significant effect $(P<0.05)$ on all traits except for calving interval and lactation length, and breeding efficiency was only affected by age at first insemination and age at first calving $(P<0.05)$.

Heritabilities were $0.27 \pm 0.08$ for milk yield, $0.02 \pm 0.05$ for lactation length, $0.06 \pm 0.05$ for calving interval, $0.05 \pm 0.05$ for breeding efficiency, $0.30 \pm 0.08$ for herd life and $0.29 \pm 0.08$ for length of productive life. Genetic and phenotypic correlations between different traits ranged from -0.49 to 0.99 and -0.37 to 0.99 respectively.
\end{abstract}

Keywords: milk yield, calving interval, breeding efficiency, herd life, length of productive life, Holstein cows

\section{Zusammenfassung}

\section{Beziehungen zwischen Milch- sowie Fruchtbarkeitsleistungen in der ersten Laktation und Lebensleistung von Holsteinkühen unter subtropischen Bedingungen}

Untersucht wurden bei 1293 Holsteinkühen der staatlichen Ceylanpinarfarm in Südostanatolien die Beziehungen zwischen der Erstlaktationsleistung, mehreren Fruchtbarkeitsmerkmalen und der Nutzungsdauer. Die durchschnittliche Laktationsleistung lag bei $5620 \mathrm{~kg}$ Milch bei eine Laktationsdauer von 316, einem Kalbeintervall von 387, einem Lebensalter von 2096 und einem Nutzungsalter von 1257 Tagen. Außer dem Kalbeintervall, dem Alter bei Erstbesamung und dem Kalbealter beeinflusste die Erstlaktationsleistung sämtliche anderen Merkmale signifikant. Die Heritabilitätsschätzwerte sowie die genetischen und phänotypischen Korrelationen werden dargestellt und diskutiert.

Schlüsselwörter: Erstlaktationsleistung, Fruchtbarkeitsmerkmale, Kalbeabstand, Lebensalter, Nutzungsdauer, Holstein Kühe 


\section{Introduction}

High milk yield, regular fertility, and improved herd and length of productive lives are desired traits for dairy animals. Latter two ones have significant effect on economic advantage by reducing replacement and increasing the number of cows producing at mature levels in a herd (SZAJKO 1987, KALM 2002). These characters are influenced by several factors such as inheritance, year, season, parity, feeding, management and age at first calving. Lower age at first calving and the ability to produce longer years are charming for high yielding cows. VUKASINOVIC et al. (2001) reported that age at first calving did not have a significant influence on the length of productive life. However, some researchers (PIRLO et al. 2000, MARTINEZ et al. 1983) emphasized that the reduced age at first calving decrease the generation interval and feed costs, but may also reduce calf liveability at the same time because of dystocia.

According to various studies herd life and length of productive life ranges from 1716 to 3737 and 903 to 2792 days in different breeds. (NIEUWHOF et al. 1989, HARRIS et al. 1992, SETTAR and WELLER 1999, FREYER and ERHARDT 2000, RIZZI et al. 2002, NILFOROOSHAN and EDRISS 2004, TSURUTA et al. 2005, GOSHU 2005, DAKAY et al. 2006)

Heritability estimates ranged from 0.22 to $0.40,0.03$ to $0.09,0.04$ to 0.14 , and 0.03 to 0.12 for first lactation milk yield, calving interval, herd life and length of productive life respectively. Genetic and phenotypic correlations of production traits with herd and length of productive lives were from -0.08 to 0.91 and 0.04 to 0.55 (VAN DOORMAL et al. 1985, HARRIS et al. 1992, JAIRATH et al. 1995, VOLLEMA and GROEN 1996, SETTAR and WELLER 1999, CRUICKSHANK et al. 2002, ROXSTRÖM and STRANDBERG 2002, HAILE-MARIAM et al. 2003a, HAILE-MARIAM et al. 2003b, SEELAND and HENZE 2003, NILFOROOSHAN and EDRISS 2004, KHATTAB et al. 2005, TSURUTA et al. 2005, GADER et al. 2007).

The purpose of this investigation was to determine relationships of first lactation milk yield and calving interval with breeding efficiency, herd and length of productive lives of Holsteins in subtropical conditions.

\section{Material and methods}

Records of 1293 Holstein cows maintained at Ceylanpınar State Farm from 1990 to 2002 were used in this study. The area has subtropical climate conditions and geographical coordinates are $36.84^{\circ} \mathrm{N}$ and $40.02^{\circ} \mathrm{E}$. The climate of area is characterized by hot summers. The meteorological data are given in Figure 1.

Milk yield, lactation length and calving interval in first lactation, and breeding efficiency, herd life and length of productive life were examined.

The breeding efficiency (BE) (WILCOX et al. 1957) was estimated as

$$
\% B E=\frac{365(N-1) \cdot 100}{D}
$$

where is $N$ the total number of parturitions and $D$ the number of days from first to last parturition.

Herd life was defined as the number of days from date of birth to date of culling. Length of productive life was defined as the number of days from first calving to date of culling. 


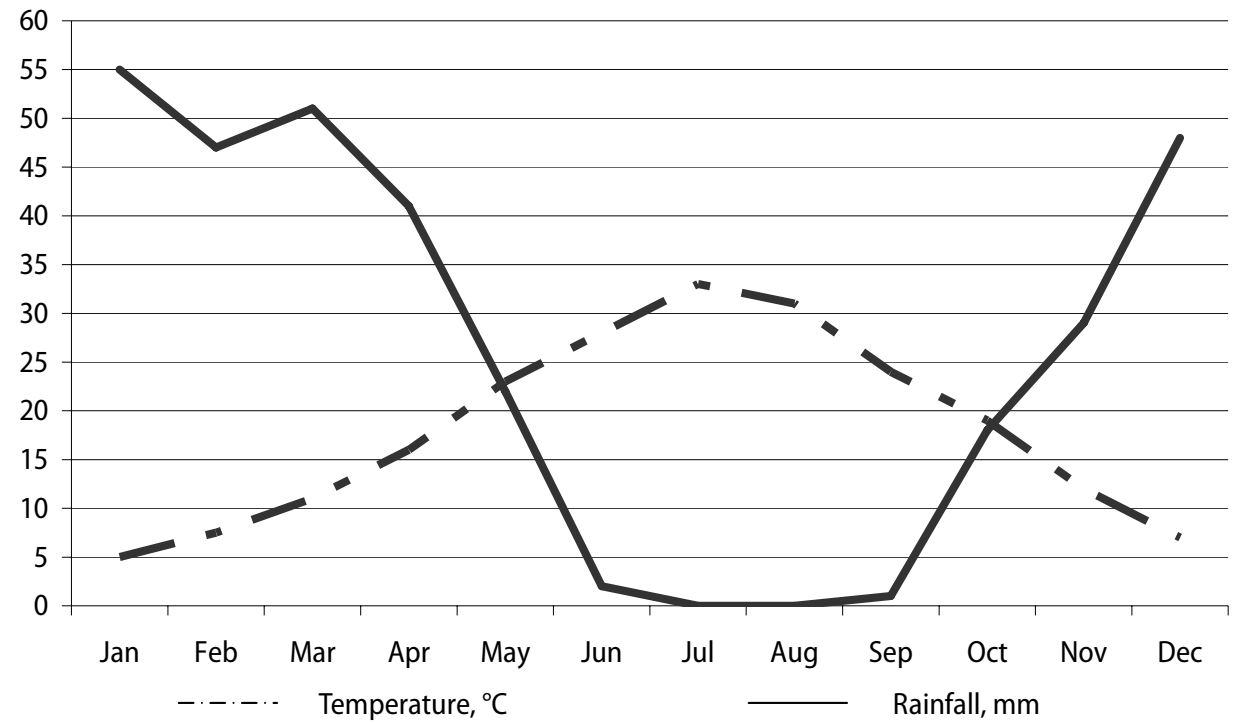

Figure 1

Temperatures and rainfall for Ceylanpınar State Farm

Temperaturen und Regenmenge im Untersuchungsbetrieb

Data were analyzed using linear mixed model least squares and maximum likelihood (LSMLMW) computer program of Harvey's (HARVEY 1987). The traits were analyzed with a model that included 1 random (sire), 4 fixed effects (first calving year and season, age at first insemination $[\mathrm{AFI}]$, age at first calving [AFC]). Calving years were grouped into 3 periods viz. (1) 1990-1994, (2) 1995-1998 and (3) 1999-2001. Calving months were classified into 4 seasons viz. (1) winter: December-February, (2) spring: March-May, (3) summer: June-August, (4) fall: September-November. AFI were classified into 3 group viz. (1) 15-17th month, (2) 18-19th month and (3) 20-25th month, and AFC were subdivided into three groups viz. (1) 24-26th month, (2) 27-28th month and (3) 29-34th month.

Only 82 sires with greater than or equal to 5 cows were included in the analysis. Heritabilities $\left(h^{2}\right)$, genetic $\left(r_{G}\right)$ and phenotypic $\left(r_{P}\right)$ correlations by paternal half-sib method were computed by LSMLMW program of Harvey's (HARVEY 1987).

\section{Results}

\section{Least-squares analysis of different traits}

The least-squares means are presented in Table 1. Calving year had significant effect $(P<0.05)$ on all traits except for lactation length and calving interval. The effect of season on milk yield, lactation length and breeding efficiency were significant $(P<0.05)$. Age at first calving were significant $(P<0.05)$ for only breeding efficiency. The over all means for milk yield, lactation length, calving interval, breeding efficiency, herd life and length of productive life were $5620.1 \pm 76.6 \mathrm{~kg}, 315.5 \pm 2.0,386.9 \pm 2.6,94.9 \pm 0.5 \%, 2095.9 \pm 34.7$, and $1257.2 \pm 34.4$ days, respectively. 
Table 1

Least squares means and standards errors for different traits

Mittelwerte nach der Methode der kleinsten Quadrate und Standardfehler der untersuchten Merkmale

\begin{tabular}{|c|c|c|c|c|c|c|c|}
\hline Classification & $N$ & $\begin{array}{l}\text { Milk Yield, } \\
\quad \text { kg } \\
\bar{X} \pm S_{\bar{X}}\end{array}$ & $\begin{array}{l}\begin{array}{c}\text { Lactation } \\
\text { length, days }\end{array} \\
\qquad \bar{X} \pm S_{\bar{X}}\end{array}$ & $\begin{array}{c}\text { Calving } \\
\text { interval, } \\
\text { days } \\
\bar{X} \pm S_{\bar{X}}\end{array}$ & 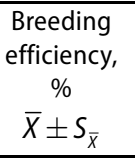 & $\begin{array}{l}\text { Herd life, } \\
\text { days } \\
\bar{X} \pm S_{\bar{X}}\end{array}$ & $\begin{array}{c}\text { Length of } \\
\text { productive life, } \\
\text { days } \\
\bar{X} \pm S_{\bar{X}}\end{array}$ \\
\hline$\mu$ & 1293 & $5620.1 \pm 76.6$ & $315.5 \pm 2.0$ & $386.9 \pm 2.6$ & $94.9 \pm 0.5$ & $2095.9 \pm 34.7$ & $1257.2 \pm 34.4$ \\
\hline Calving year & & $* *$ & & & $* *$ & $* *$ & $* *$ \\
\hline 1990-1994 & 370 & $5006.0 \pm 156.7^{b}$ & $305.2 \pm 6.0^{\mathrm{a}}$ & $371.3 \pm 7.1^{\mathrm{a}}$ & $99.1 \pm 1.3^{\mathrm{a}}$ & $2487.1 \pm 69.1^{\mathrm{a}}$ & $1651.8 \pm 69.0^{a}$ \\
\hline 1995-1998 & 693 & $6070.9 \pm 122.6^{a}$ & $315.9 \pm 4.4^{\mathrm{a}}$ & $391.8 \pm 5.3^{\mathrm{a}}$ & $94.0 \pm 1.0^{\mathrm{b}}$ & $2002.9 \pm 54.4^{b}$ & $1165.0 \pm 54.2^{b}$ \\
\hline 1999-2001 & 230 & $5783.4 \pm 169.0^{a}$ & $325.5 \pm 6.5^{\mathrm{a}}$ & $397.4 \pm 7.8^{\mathrm{a}}$ & $91.5 \pm 1.4^{b}$ & $1797.6 \pm 74.5^{c}$ & $954.8 \pm 74.4^{c}$ \\
\hline Season & & $* *$ & * & & * & & \\
\hline Winter & 334 & $5822.2 \pm 101.4^{\mathrm{a}}$ & $317.6 \pm 3.4^{\mathrm{ab}}$ & $389.2 \pm 4.1^{\mathrm{a}}$ & $95.3 \pm 0.7^{\mathrm{a}}$ & $2118.6 \pm 45.3^{a}$ & $1280.8 \pm 45.0^{\mathrm{a}}$ \\
\hline Spring & 405 & $5843.4 \pm 96.4^{a}$ & $321.7 \pm 3.1^{\mathrm{a}}$ & $392.2 \pm 3.8^{\mathrm{a}}$ & $93.4 \pm 0.7^{b}$ & $2110.5 \pm 43.1^{a}$ & $1273.0 \pm 42.9^{\mathrm{a}}$ \\
\hline Summer & 288 & $5317.8 \pm 104.5^{b}$ & $310.2 \pm 3.6^{\mathrm{b}}$ & $385.5 \pm 4.3^{\mathrm{a}}$ & $94.8 \pm 0.8^{\mathrm{ab}}$ & $2070.5 \pm 46.6^{\mathrm{a}}$ & $1230.5 \pm 46.4^{\mathrm{a}}$ \\
\hline Autumn & 266 & $5497.0 \pm 107.8^{b}$ & $312.6 \pm 3.7^{b}$ & $380.6 \pm 4.4^{\mathrm{a}}$ & $96.0 \pm 0.8^{\mathrm{a}}$ & $2083.9 \pm 47.7^{\mathrm{a}}$ & $1244.5 \pm 47.5^{\mathrm{a}}$ \\
\hline \multicolumn{8}{|c|}{ Age at first insemination, month } \\
\hline $15-17$ & 602 & $5738.4 \pm 124.1^{\mathrm{a}}$ & $318.0 \pm 4.5^{\mathrm{a}}$ & $390.6 \pm 5.4^{\mathrm{a}}$ & $93.2 \pm 1.0^{\mathrm{a}}$ & $2078.6 \pm 55.0^{\mathrm{a}}$ & $1266.4 \pm 54.9^{\mathrm{a}}$ \\
\hline $18-19$ & 477 & $5564.8 \pm 106.4^{a}$ & $314.5 \pm 3.7^{\mathrm{a}}$ & $384.1 \pm 4.4^{\mathrm{a}}$ & $94.3 \pm 0.8^{\mathrm{a}}$ & $2100.3 \pm 47.4^{a}$ & $1268.3 \pm 47.2^{\mathrm{a}}$ \\
\hline $20-25$ & 214 & $5557.1 \pm 162.8^{a}$ & $314.0 \pm 6.3^{\mathrm{a}}$ & $385.8 \pm 7.4^{\mathrm{a}}$ & $97.1 \pm 1.4^{\mathrm{a}}$ & $2108.8 \pm 71.8^{\mathrm{a}}$ & $1236.8 \pm 71.7^{a}$ \\
\hline \multicolumn{4}{|c|}{ Age at first calving, month } & & * & & \\
\hline $24-26$ & 504 & $5489.9 \pm 140.6^{a}$ & $310.5 \pm 5.3^{\mathrm{a}}$ & $376.6 \pm 6.3^{\mathrm{a}}$ & $96.8 \pm 1.1^{\mathrm{a}}$ & $2059.0 \pm 62.1^{\mathrm{a}}$ & $1261.8 \pm 62.0^{\mathrm{a}}$ \\
\hline $27-28$ & 509 & $5566.5 \pm 109.4^{a}$ & $314.6 \pm 3.8^{\mathrm{a}}$ & $386.2 \pm 4.6^{a}$ & $95.8 \pm 0.8^{a}$ & $2106.3 \pm 48.7^{a}$ & $1275.3 \pm 48.5^{\mathrm{a}}$ \\
\hline $29-34$ & 280 & $5803.8 \pm 136.8^{a}$ & $321.4 \pm 5.1^{\mathrm{a}}$ & $397.7 \pm 6.1^{\mathrm{a}}$ & $92.1 \pm 1.1^{\mathrm{b}}$ & $2122.4 \pm 60.5^{\mathrm{a}}$ & $1234.5 \pm 60.4^{\mathrm{a}}$ \\
\hline
\end{tabular}

a,b,c, subclass means followed by different superscripts are significantly different $(P<0.05), \quad{ }^{*} P<0.05, \quad{ }^{*} P<0.01$

\section{Heritabilities, genetic and phenotypic correlations}

Heritabilities, genetic and phenotypic correlations among investigated traits are shown in Table 2.

Table 2

Heritabilities, genetic and phenotypic correlations among different traits ${ }^{1}$

Heritabilitätsschätzwerte, genetische und phänotypische Korrelationen der untersuchten Merkmale

\begin{tabular}{lcccccc}
\hline Traits & $\begin{array}{c}\text { Milk } \\
\text { yield }\end{array}$ & $\begin{array}{c}\text { Lactation } \\
\text { length }\end{array}$ & $\begin{array}{c}\text { Calving } \\
\text { interval }\end{array}$ & $\begin{array}{c}\text { Breeding } \\
\text { efficiency }\end{array}$ & $\begin{array}{c}\text { Herd } \\
\text { life }\end{array}$ & $\begin{array}{c}\text { Length of } \\
\text { productive } \\
\text { life }\end{array}$ \\
\hline Milk yield & $0.27 \pm 0.08^{* *}$ & $0.70 \pm 0.47$ & $0.16 \pm 0.36$ & $-0.49 \pm 0.54$ & $0.08 \pm 0.21$ & $0.08 \pm 0.21$ \\
Lactation length & 0.63 & $0.02 \pm 0.05$ & $0.64 \pm 0.44$ & $<-1^{+}$ & $0.10 \pm 0.53$ & $0.107 \pm 0.54$ \\
Calving interval & 0.51 & 0.88 & $0.06 \pm 0.05$ & $<-1^{\dagger}$ & $-0.22 \pm 0.37$ & $-0.21 \pm 0.37$ \\
Breeding efficiency & -0.37 & -0.61 & -0.72 & $0.05 \pm 0.05$ & $0.19 \pm 0.41$ & $0.17 \pm 0.41$ \\
Herd life & 0.06 & -0.01 & -0.01 & -0.11 & $0.30 \pm 0.08^{* *}$ & $0.99 \pm 0.00^{*}$ \\
Length of & 0.05 & -0.02 & -0.01 & -0.11 & 0.99 & $0.29 \pm 0.08^{* *}$ \\
productive life & 0.01 & & & &
\end{tabular}

${ }^{1}$ Diagonals are heritabilities, upper-off diagonals are genetic correlations, lower-off diagonals are phenotypic correlations. ${ }^{+}$The estimates of these genetic correlations are outside the parameter limits of -1 and +1 in our data. ${ }^{* *} P<0.01,{ }^{*} P<0.05$ Significance levels were seen by ANOVA in heritabilities and calculated as by ZAR (1984) in genetic correlations. 


\section{Discussion}

\section{Least-squares analysis of different traits}

Significant $(P<0.05)$ effects of calving year and least-squares means showed that while the milk yields increased breeding efficiency, herd life and length of productive life decreased with the advancing years. The fact that the fertility and longevity may be depressed while trying to boost milk production by changing feeding and management conditions throughout the years may explain this phenomenon. First lactation milk yield and breeding efficiency were found to be higher in relatively cool season calvers. In addition to green fodder and first-cut silage, low ambient temperatures during these seasons may result in improved performance. Heifers that freshened at younger ages had better herd life and length of productive life. The average for first lactation milk yield was between the values of OJANGO and POLLOT (2001) and JAIRATH et al. (1995) for Holsteins. The mean for breeding efficiency $(94.87 \%)$ was higher than the values reported by AGEEB and HAYES (2000), GOSHU (2005), and WILCOX et al. (1957) in dairy herds. Different breeds, feeding, management, climatic conditions and calculation methods might cause this.

The averages for herd life (2095.9 days) and length of productive life (1 257.2 days) were in the range of 1716-3 737 and 903-2 792 days described by early research (LIN et al. 1988, NIEUWHOF et al. 1989, HARRIS et al. 1992, SETTAR and WELLER 1999, RIZZI et al. 2002, NILFOROOSHAN and EDRISS 2004, TSURUTA et al. 2005, GOSHU 2005, DAKAY et al. 2006).

\section{Heritabilities, genetic and phenotypic correlations}

The heritabilities were moderate for milk yield $(0.27 \pm 0.08)$, and low for lactation length $(0.02 \pm 0.05)$ and calving interval $(0.06 \pm 0.05)$. This is in agreement with the findings of various workers (HOEKSTRA et al. 1994, OJANGO and POLLOT 2001, HAILE-MARIAM et al. 2003a, DEMATAWEWA and BERGER 1998, CAMPOS et al. 1994, JAIRATH et al. 1995). Heritability for breeding efficiency (0.05) was lower than that of WILCOX et al. (1957). This could be due to the influence of some non-tangible environmental factors that may be specific to each animal besides the factors included in the least squares model. The moderate heritabilities were also estimated 0.30 and 0.29 for herd life and length of productive life. These findings were higher than the values announced by several researchers (VAN DOORMAL et al. 1985, HARRIS et al. 1992, JAIRATH et al. 1995, VOLLEMA and GROEN 1996, SETTAR and WELLER 1999, ROXSTRÖM and STRANDBERG 2002, NILFOROOSHAN and EDRISS 2004, TSURUTA et al. 2005, MESZAROS et al. 2008) except WILCOX et al. (1957). Correlations of first lactation production and fertility traits with longevity were relatively lower than the findings of several researchers (VAN DOORMAL et al. 1985, HARRIS et al. 1992, JAIRATH et al. 1995, VOLLEMA and GROEN 1996, SETTAR and WELLER 1999, ROXSTRÖM and STRANDBERG 2002, NILFOROOSHAN and EDRISS 2004, TSURUTA et al. 2005). This may be from the methods of estimation.

In conclusion, some environmental factors had significant effects $(P<0.05)$ influence on life long performance in this study. This must be considered when breeding values are computed. First lactation milk yield, herd life and length of productive life were found to be more heritable. Therefore, these traits may be preferred by breeders as selection 
criteria. Although correlations of the first lactation production and reproduction with longevity traits were non-significant, larger investigations would be useful due to undesirable way correlations of calving interval with milk yield, breeding efficiency, herd life and length of productive life.

\section{Acknowledgements}

Assistance of Turkish Agricultural Ministry and Ceylanpınar State Farm is gratefully acknowledged.

\section{References}

Ageeb AG, Hayes JF (2000) Reproductive responses of Holstein-Friesian cattle to the climatic conditions of Central Sudan. Trop Anim Health Prod 32, 233-43

Amin AAR, Toth S, Gere T (1996) Selection indices for improvement milk and fat yield based on age at first mating and calving under Hungarian conditions. Arch Tierz 39, 25-32

Campos MS, Wilcox CJ, Beceril CM, Diz A (1994) Genetic parameters for yield and reproductive traits of Holstein and Jersey cattle in Florida. J Dairy Sci 77, 867-73

Cruickshank J, Weigel KA, Dentine MR, Kirkpatrick BW (2002) Indirect prediction of herd life in Guernsey dairy cattle. J Dairy Sci 85, 1307-13

Dákay I, Márton D, Bene S, Kiss B, Zsuppán Z, Szabó F (2006) The age at first calving and the longevity of beef cows in Hungary. Arch Tierz 49, 417-25

Dematawewa CMB, Berger PJ (1998) Genetic and phenotypic parameters for 305-day yield, fertility, and survival in Holsteins. J Dairy Sci 81, 2700-9

Freyer G, Erhardt G (2000) First results of a MAS study in dairy cattle with respect to longevity. Arch Tierz 43, 241-7

Gader AA, Ahmed MA, Musa LMA, Peters KJ (2007) Milk yield and reproductive performance of Friesian cows under Sudan tropical conditions. Arch Tierz 50, 155-64

Goshu G (2005) Breeding efficiency, lifetime lactation and calving performance of Friesian-Boran crossbred cows at Cheffa farm, Ethiopia. Livest Res Rural Develop 17, 7

Haile-Mariam M, Bowman PJ, Goddard ME (2003a) Genetic and environmental relationship among calving interval, survival, persistency of milk yield and somatic cell count in dairy cattle. Livest Prod Sci 80, 189-200

Haile-Mariam M, Morton JM, Goddard ME (2003b) Estimates of genetic parameters for fertility traits of Autralian Holstein-Friesian cattle. Anim Sci 76, 35-42

Harris BL, Freeman AE, Metzger E (1992) Analysis of Herd Life in Guernsey Dairy Cattle. J Dairy Sci 75, 2008-16

Harvey WR (1987)User's guide for LSMLMW PC-1 version, Mixed model Least-squares and maximum likelihood computer program. Mimeo. Ohio State Univ., Columbus, USA

Hoekstra J, Van der Lugt AW, Van der Werf JHJ, Ouweltjes W (1994) Genetic and phenotypic parameters from milk production and fertility traits in upgraded dairy cattle. Livest Prod Sci 40, 225-32

Jairath LK, Hayes JF, Cue RI (1995) Correlations between first lactation and lifetime performance traits of Canadian Holsteins. J Dairy Sci 78, 438-48

Kalm E (2002) Development of cattle breeding strategies in Europe. Arch Tierz 45, 5-12

Khattab AS, Atil H, Badawy L (2005) Variances of direct and maternal genetic effects for milk yield and age at first calving in a herd of Friesian cattle in Egypt. Arch Tierz 43, 24-31

Martinez ML, Freeman AE, Berger PJ (1983) Genetic relationship between calf livability and calving difficulty of Holsteins. J Dairy Sci 66, 1494-502

Mészáros G, Fuerst-Waltl B, Kadlečík O, Kasarda R, Sölkner R (2008) Genetic evaluation for length of productive life in Slovak Pinzgau cattle. Arch Tierz 51, 438-48

Nieuwhof GJ, Norman HD, Dickinson FN (1989) Phenotypic trends in herd life of dairy cows in the United States. J Dairy Sci 72, 726-36

Nilforooshan MA, Edriss MA (2004) Effect of Age at First Calving on Some Productive and Longevity Traits in Iranian Holsteins of the Isfahan Province. J Dairy Sci 87, 2130-5 
Ojango JMK, Pollott GE (2001) Genetics of milk yield and fertility traits in Holstein Friesian cattle on large-scale Kenyan farms. J Anim Sci 79, 1742-50

Pirlo G, Miglior F, Speroni M (2000) Effect of age at first calving on production traits and on difference between milk yield returns and rearing costs in Italian Holsteins. J Dairy Sci 83, 603-8

Rizzi, R, Bagnato A, Cerutti F, Alvarez JC (2002) Lifetime performances in Carora and Holstein cows in Venezuela. J Anim Breed Genet 119, 83-92

Roxström A, Strandberg E (2002) Genetic analysis of functional fertility, mastitis and productiondetermined length of productive life in Swedish dairy cattle. Livest Prod Sci 74, 125-35

Seeland G, Henze C (2003) Relations between milk yield and fertility after strong increased milk yield. Arch Tierz 46, 103-12 [in German]

Settar P, Weller J (1999) Genetic Analysis of Cow Survival in the Israeli Dairy Cattle Population. J Dairy Sci $82,2170-7$

Szajko $L$ (1987) Comparison of dairy cattle breeds on the basis of the relative lifetime performance. Arch Tierz 30, 373-82

Tsuruta S, Misztal I, Lawlor TJ (2005) Changing Definition of Productive Life in US Holsteins: Effect on Genetic Correlations. J Dairy Sci 88, 1156-65

Van Doormaal Bj, Schaeffer Lr, Kennedy BW (1985) Estimation of genetic parameters for stayability in Canadian Holstein. J Dairy Sci 68, 1763-9

Vollema Ar, Groen AF (1996) Genetic parameters of longevity traits of an upgrading population of dairy cattle. J Dairy Sci 79, 2261-7

Vukasinovich N, Moll J, Casanova L (2001) Implementation of a routine genetic evaluation for longevity based on survival analysis techniques in dairy cattle populations in Switzerland. J Dairy Sci 84, 2073-80

Wilcox CJ, Pfau KO, Bartlett JW (1957) An investigation of the inheritance of female reproductive performance and longevity, and their interrelationships with in a Holstein-Friesian herd. J Dairy Sci $40,942-7$

Zar JH (1984) Biostatistical Analysis, 2nd ed. Prentice-Hall Inc., Englewood Cliffs, NJ, USA

Received 24 September 2008, accepted 28 April 2009.

Corresponding author:

Dr. SERDAR KOÇAK

email: serkocak@yahoo.com

Department of Animal Science, Faculty of Veterinary Medicine, Afyon Kocatepe University, ANS Campus,

Afyonkarahisar, Turkey 